\title{
The Transformation of Dryland Rivers: The Future of Introduced Tamarisk in the U.S.
}

\begin{abstract}
Tamarix spp. (tamarisk or saltcedar), a shrub-like tree, was intentionally introduced to the U.S. from Asia in the mid-1800s. Tamarisk thrives in today's human-altered streamside (riparian) habitats and can be found along wetlands, rivers, lakes, and streams across the western U.S. In 2001, a biological control agent, Diorhabda spp. (tamarisk leaf beetle), was released in six states, and has since spread throughout the southwestern U.S. and northern Mexico. Beetle defoliation of tamarisk has altered tamarisk's water use and effectiveness as erosion control, as well as dynamics of native and nonnative plant and wildlife species. The full effects of the tamarisk leaf beetle on ecosystem function remain unknown. The U.S. Geological Survey collaborates with Tribal, State, Federal agencies, and other institutions to provide current, fact-based information on the effects of tamarisk and the tamarisk leaf beetle on managed resources, and provides sound science for conservation and restoration of riparian habitats in the southwestern U.S.
\end{abstract}

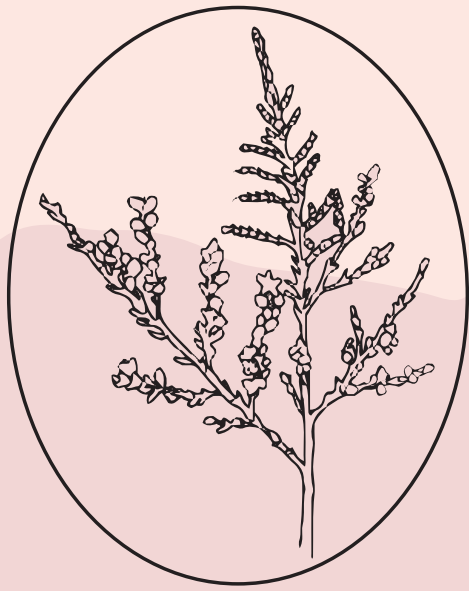

\section{Tamarisk and Riparian Systems}

Streamside (riparian) habitat occupies less than 10 percent of the Southwestern landscape. Yet, it is the most critical ecosystem in drylands, providing habitat for more than 90 percent of wildlife species and provides other ecological functions. Thus, riparian habitats receive considerable attention, resources, and management action. The success of nonnative Tamarix spp. (tamarisk or saltcedar) in riparian habitats across the Southwest has led to large changes in biological and geomorphological processes.

Several factors have contributed to the success of tamarisk in the western U.S. Tamarisk produce seeds that are dispersed by wind and water throughout the spring and summer. Tamarisk has small, needle-like, salt-exuding leaves that allow them to tolerate high-levels of salinity, drought, and heat. Tamarisk may be favored in areas along river courses (1) that have altered flood regimes, (2) that are saltier due to the effects of dams and water diversions, (3) with less available water because streams are undergoing pressures from drought and increased temperatures, and (4) with declining groundwater levels owing to over-extraction and limited recharge.

The spread of tamarisk in the west coincided with a decline in the ecological function of many riparian habitats in the early 20th century. Rivers and streams were dammed and (or) water was diverted for irrigation purposes separate from but concurrent with the introduction of tamarisk to the U.S. Increasing concern over the spread of tamarisk led to the release of a biological control agent, Diorhabda carinulata (northern tamarisk leaf beetle), starting in 2001. The beetles were released in six states - California, Colorado, Nevada, Texas, Utah, and Wyoming - by the U.S. Department of Agriculture's Animal and
Plant Health Inspection Service. Since 2001, additional tamarisk leaf beetle species have been introduced and have spread to adjoining states and northern Mexico.

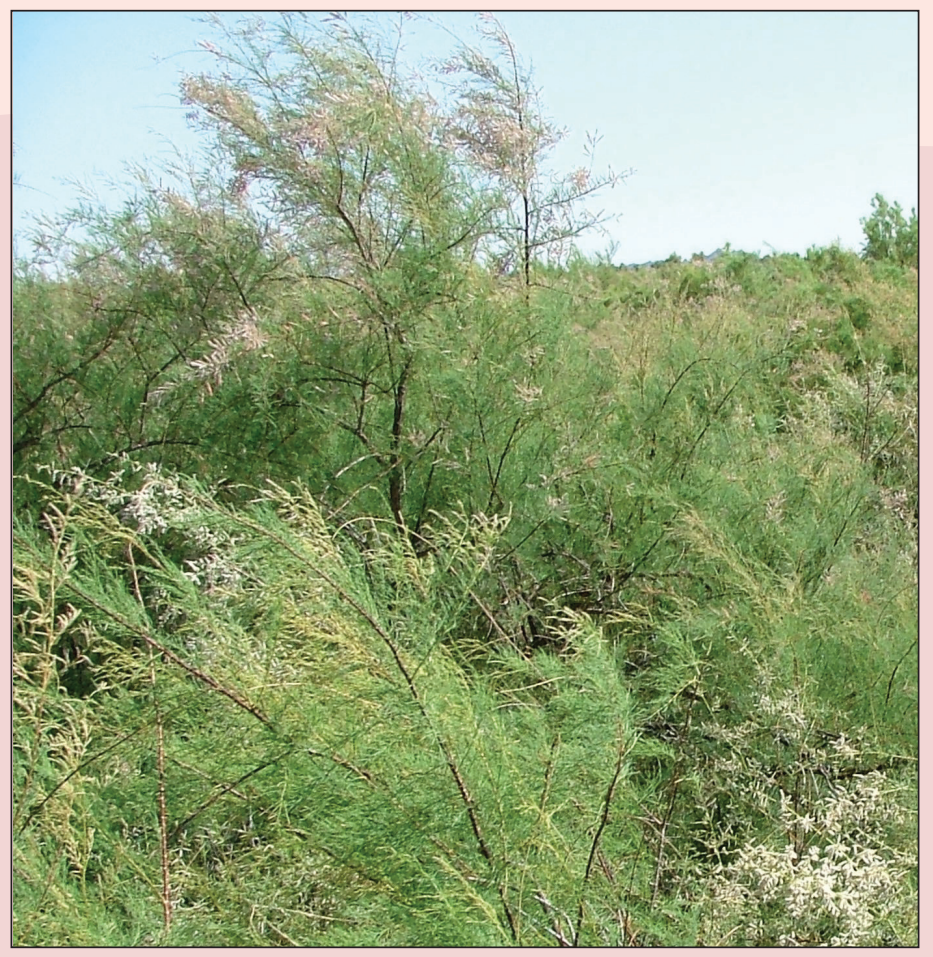

Photograph of a tamarisk plant. Photograph by Pamela Nagler, U.S. Geological Survey. 


\section{Monitoring Beetle Defoliation and Tamarisk Response}

Several ecosystem functions, such as wildlife habitat and water use, are affected by tamarisk biocontrol. USGS scientists and collaborators use remote sensing, time-lapse digital photography, and ground measurement techniques to monitor where the beetles are, how fast they spread, and what effects they are having on tamarisk. Although beetles typically cause nearly 100 percent defoliation, tamarisk is rarely killed by a single event. Several defoliation events can occur in a single year, but substantial branch die-back (a portion, but not all, of the canopy dies) or tamarisk mortality typically results after multiple years of repeated defoliation events. Difference in die-back and mortality response could be linked to plant genetics, soil microbe, or environmental conditions, such as, air temperature, streamflow patterns, depth to groundwater, soil salinity, and in-stream water salinity.

\section{Tamarisk as Wildlife Habitat}

Riparian habitats support many wildlife species and act as migratory routes for nesting and breeding birds. The movement of birds along rivers and streams evolved to coincide with available food and habitat from native trees. Tamarisk provides habitat for a wide variety of birds, reptiles, and small mammals, although the quality of that habitat may differ for different wildlife species and on how much tamarisk is present. Tamarisk can form large, single-species groups of trees called stands, or it can grow in mixed stands alongside native riparian trees and shrubs, such as cottonwoods and willows.

Single-species tamarisk and mixed stands have different ecosystem functionality. Single-species tamarisk stands host fewer arthropods, such as insects and spiders, which are important prey for many birds, reptiles, and small mammals. Temperatures in tamarisk canopies can be warmer than those of native trees - a difference between life and death for some birds and other animals that live there. Defoliation by tamarisk

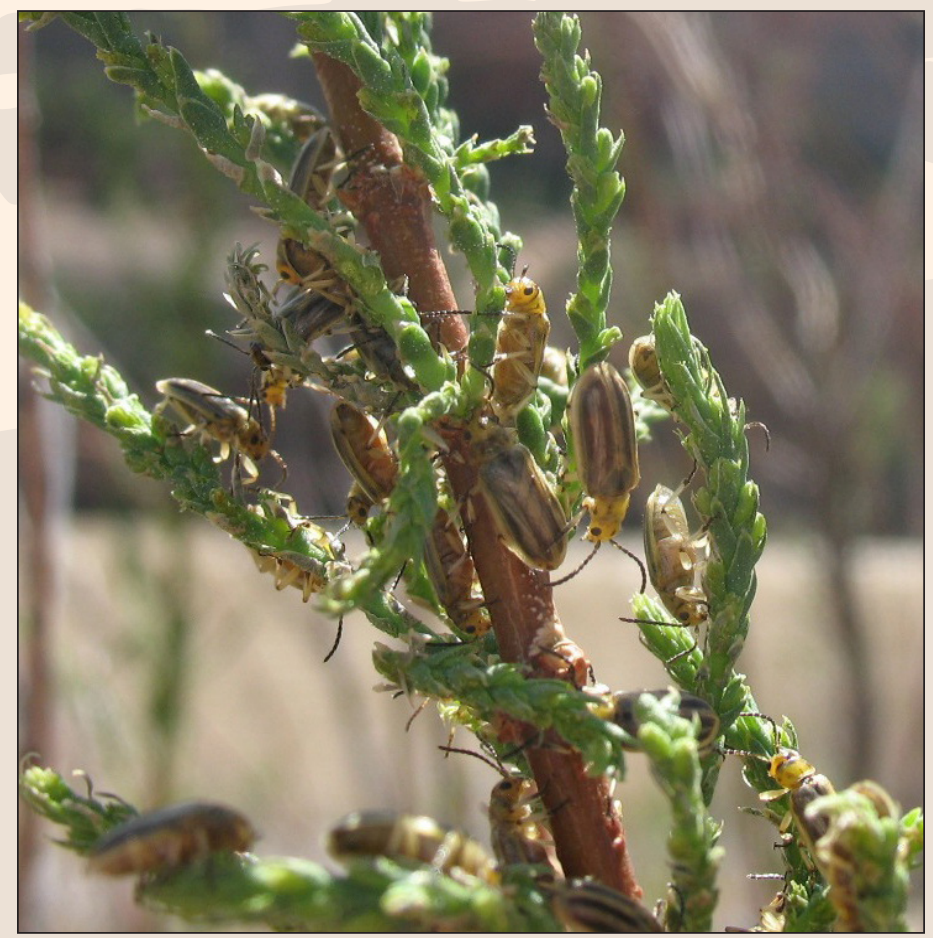

Photograph showing tamarisk biocontrol, the Diorhabda spp. (tamarisk leaf beetle). Photograph by Dan Bean.

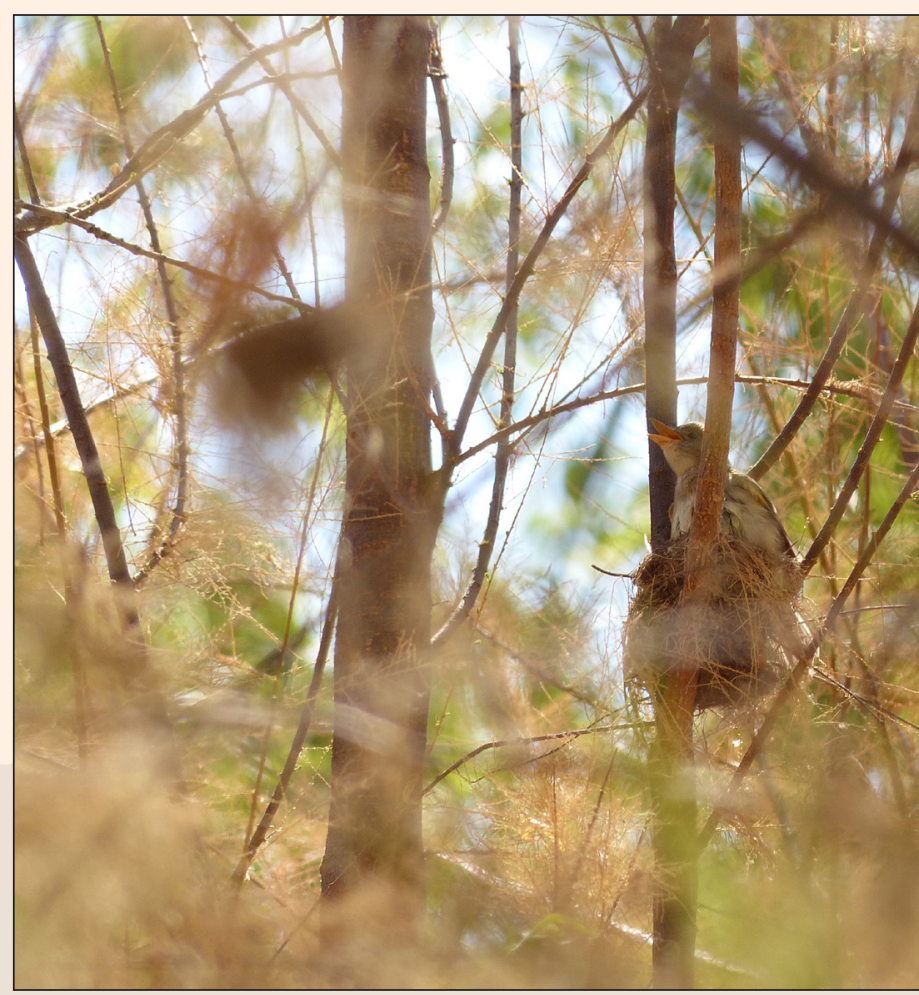

Photograph of a southwestern willow flycatcher. Photograph by Osvel Hinojosa-Huerta, Cornell Lab of Ornithology.

leaf beetles greatly increases temperature, reduces humidity, and increases solar radiation in tree canopies that can lead to nest abandonment and failure. Yet many bird species successfully nest in tamarisk, and small mammals and reptiles use tamarisk as habitat at roughly equal rates as native trees. Mixed stands support more biodiversity than native stands. Mixed stands have a higher number of arthropod species than single-species tamarisk stands or native stands, resulting in more food for reptiles, birds, and small mammals. Defoliation of single species stands by tamarisk leaf beetles may result in the further degradation of the only remaining habitat.

\section{Endangered Southwestern Willow Flycatchers and Tamarisk Leaf Beetles}

The case of the endangered Empidonax traillii extimus (southwestern willow flycatcher) exemplifies the complexities associated with wildlife habitat use of riparian habitats in the context of tamarisk biocontrol. Many breeding sites of this bird species are dominated by tamarisk. The birds will nest in singlespecies tamarisk, mixed, or native stands if standing water or moist soils are present. Defoliation by tamarisk leaf beetles can lead to higher rates of nest abandonment, further threatening this endangered species.

Tamarisk leaf beetles were not expected to move south into the bird's range because (1) the beetles were expected to spread only a few miles per year, and (2) their range was thought to be limited by daylength requirements; the beetles need a certain number of nighttime hours to complete their lifecycle. However, tamarisk leaf beetles can move about 25 miles (40 kilometers) per year and have rapidly evolved to complete their lifecycles much farther south than originally predicted. This has resulted in beetles defoliating tamarisk in the southwestern willow flycatcher range. 


\section{Water Use by Tamarisk}

Previous studies reported that tamarisk uses water at much higher rates than native plants, resulting in calls for tamarisk's eradication to conserve water resources. However, more recent research has consistently shown that tamarisk uses about the same or less water than many native woody plants. Therefore, the removal and replacement of tamarisk with native species will likely not increase water availability for agriculture, municipalities, and other uses. Beetle defoliation of tamarisk has altered tamarisk's water use, in addition to the effectiveness of tamarisk in erosion control, and riparian health related to native plant and wildlife species.

Tamarisk is more drought tolerant than native cottonwood and willow species; its roots can access deeper groundwater sources, and it can withstand drier conditions for longer periods. The combination of deeper roots and higher drought tolerance allows tamarisk to occupy areas that are farther away from primary rivers or stream channels than native species. Consequently, the expansion of tamarisk in some riparian systems could result in slight increases in water usage and reduced groundwater recharge in some areas.

If management goals are only concerned with reducing water use from vegetation, then replacing tamarisk with native cottonwood and willow is not likely to reduce water loss because native species, in some cases, use more water than tamarisk. However, water use of plants depends on many factors, including the assemblage of plant species, stand density, age, and rooting depth among other factors. Management decision making about reducing water use by vegetation includes many factors beyond identifying a target species.

Tamarisk leaf beetles were expected to help increase water levels in streams by reducing tamarisk cover through defoliation.
Green-leaf die-back, or even plant death, results when foliage is removed and transpiration (water loss via plant leaves) is reduced. This in turn, results in water savings at the plant-level, river reach-level, and (or) landscape-level following beetle defoliation. Water savings depend on how large the defoliated tamarisk stands were, their age, and how much area they covered. Furthermore, water savings are often short-lived. Once a tamarisk has grown new foliage, typically within one month, water use returns to pre-defoliation levels. Small water savings could result after multiple defoliation events if (1) fewer leaves are produced, (2) there is branch die-back and (or) (3) mortality occurs. However, even when tamarisk mortality does occur, water savings may be relatively short-lived, because other vegetation typically grows in place of tamarisk within a few years.

\section{Tamarisk and Wildfire}

Tamarisk can increase the risk of wildfire in riparian areas. Historically, riparian areas had infrequent wildfires and most native tree species are not well adapted to fire. Compared to native cottonwood and willow trees, tamarisk is highly flammable owing to a suite of chemicals and lower moisture content in its leaves and stems relative to native trees. Tamarisk is also better able to recover from wildfires than native trees.

Defoliation caused by the tamarisk leaf beetle can increase the frequency and intensity of fire in riparian systems. Defoliated tamarisk results in reduced moisture content in the plant stand, making them more flammable. Beetle defoliation also results in a thicker layer of highly flammable leaf litter on the ground, further resulting in more intense fires that spread quickly in defoliated stands.

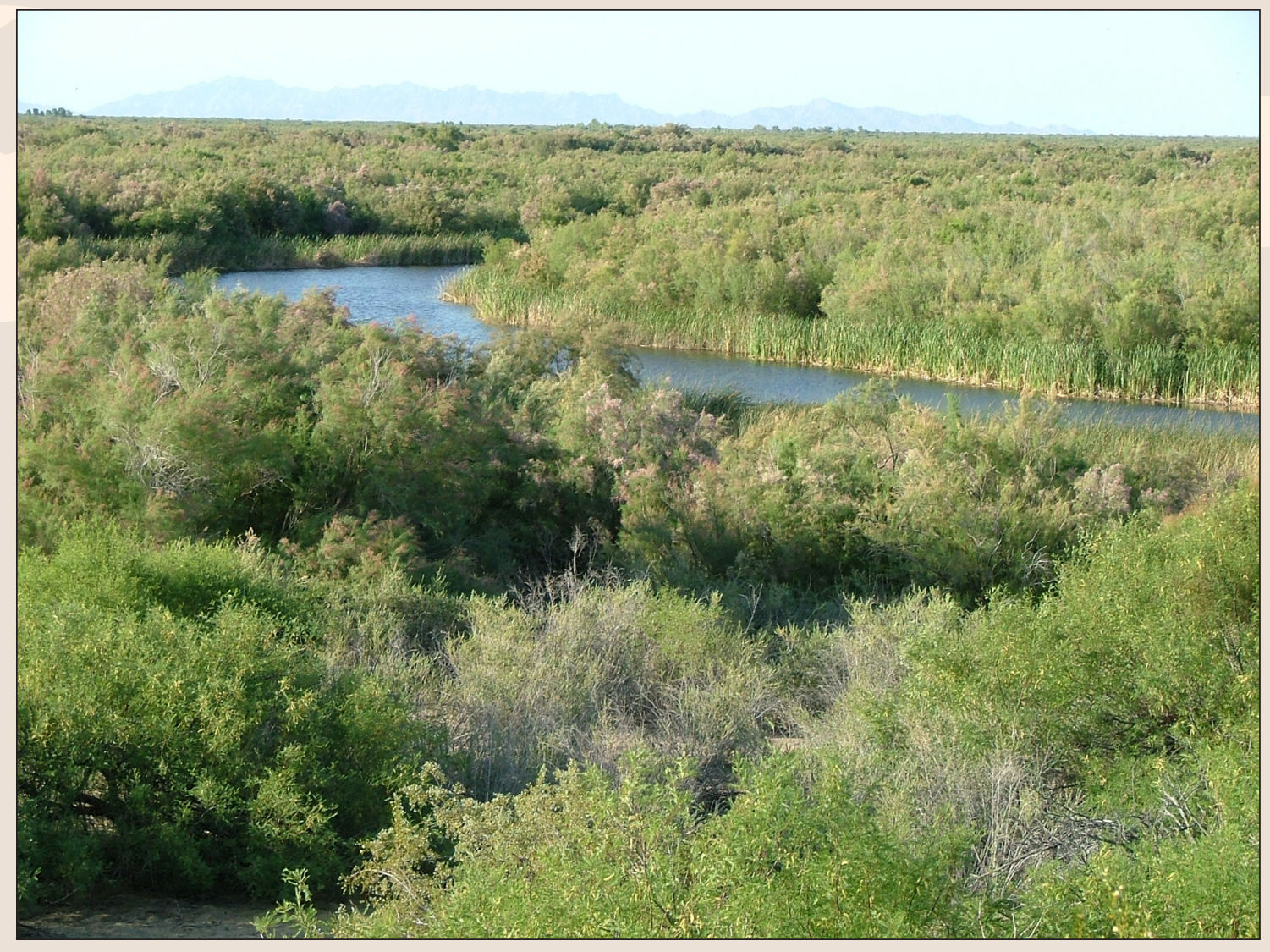

Photograph of single species stands of tamarisk on the lower Colorado River at Cibola National Wildlife Refuge, California. Photograph by Pamela Nagler, U.S. Geological Survey. 
Photographs of a wide area view of tamarisk across the Virgin River floodplain from cameras mounted on a tower on May 19, 2011 (top), and defoliated tamarisks on nearly the same area on June 19, 2011 (right). Photograph by Pamela Nagler, U.S. Geological Survey.
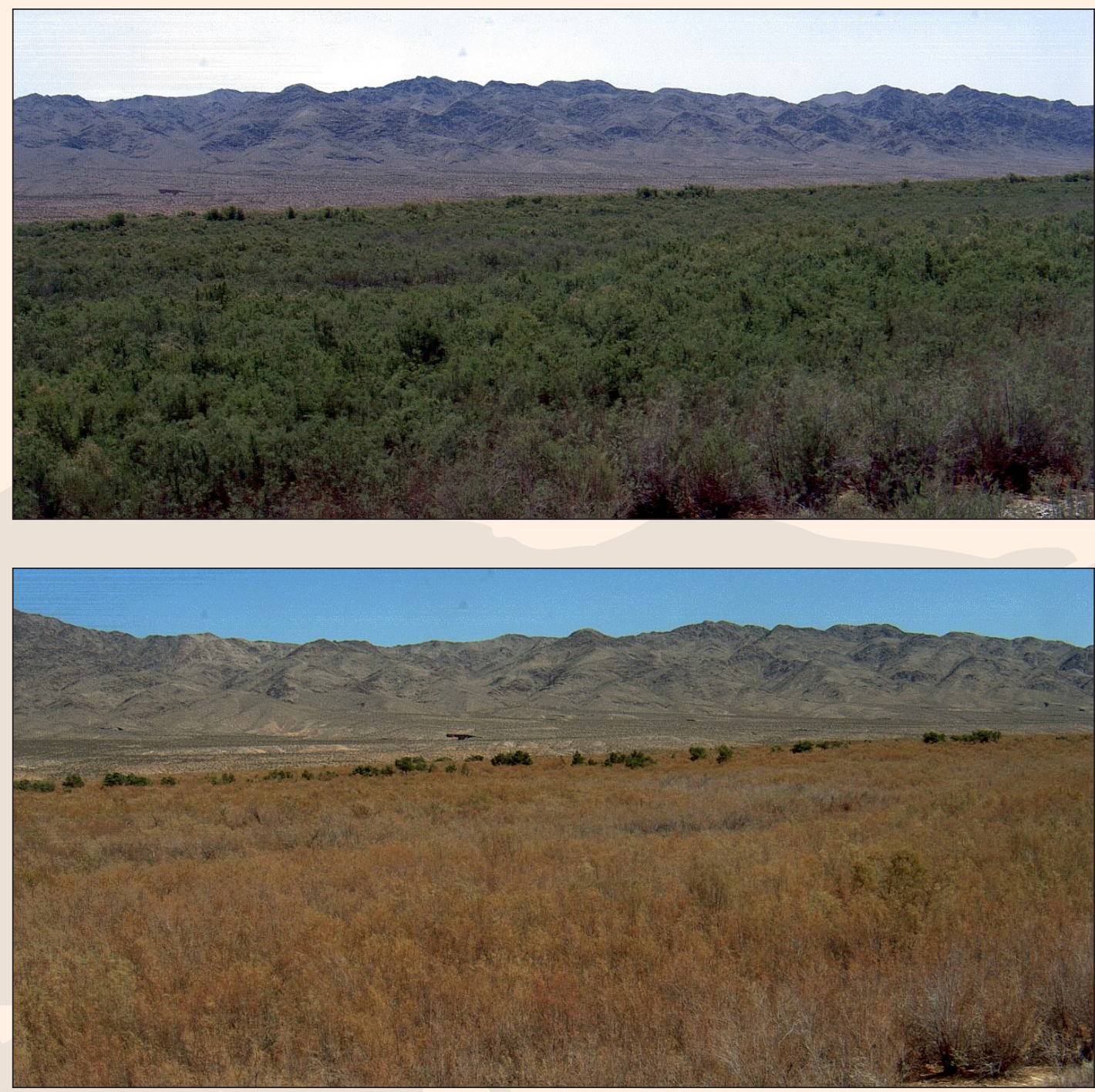

\section{Management Options for Tamarisk}

Land managers face many challenges because tamarisk has a broad geographic range and thrives under various environmental conditions. Similar management strategies may have different results in different areas and conditions. Additionally, stakeholders and land managers have various and diverse objectives and perspectives regarding the management of tamarisk. Land managers and stakeholders have different views about the mechanisms that have led to tamarisk's success in the Southwest. Those views determine the management strategies employed.

One view is that tamarisk outcompetes native vegetation and decreases riparian habitat value. Land managers that support this view tend to favor eradication through mechanical, chemical, and (or) biocontrol means. Tamarisk die-off or removal does not necessarily mean that native riparian vegetation will return. In fact, other nonnative species often are the first to establish following tamarisk removal or defoliation.

The alternative view is that invasions primarily occur on degraded riparian corridors because it is more stress tolerant than native species. Thus, the apparent replacement of cottonwood and willow by tamarisk occurs along altered river systems that may not be habitable by native trees. Land managers that support this view tend to use tamarisk as a substitute for native trees because it may be the only riparian tree that can provide some ecosystem functions. This management strategy can provide sustainable mixed stands.

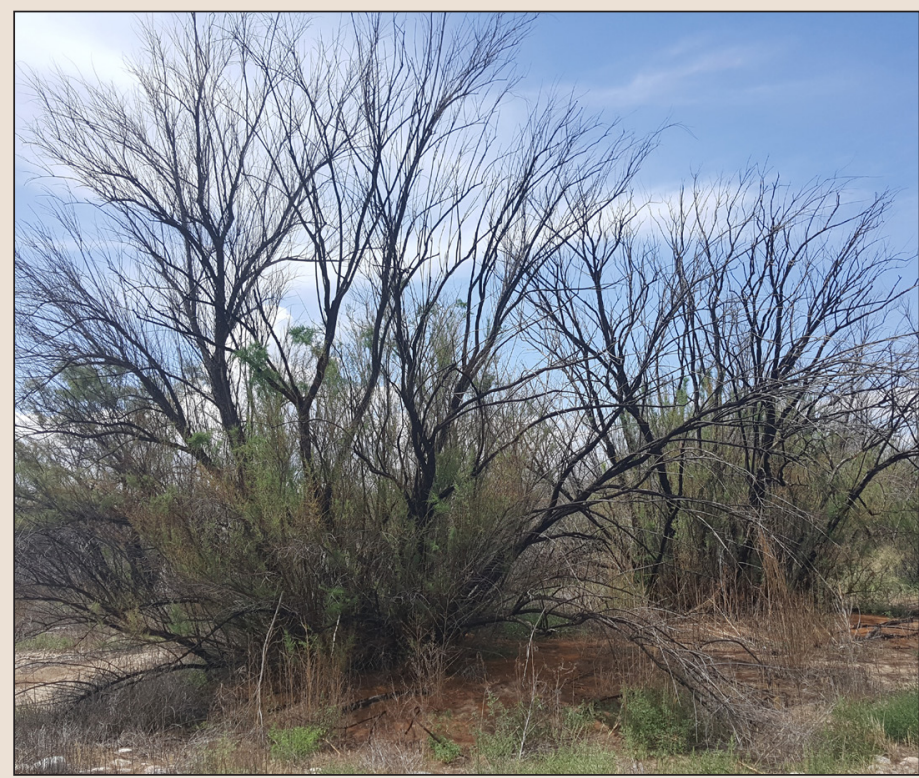

Photograph of tamarisk resprouting after a fire in 2006. Photograph by Pamela Nagler, U.S. Geological Survey. 
Many factors contribute to land management decisions. Sometimes, restoration is not logistically or financially feasible. Other times, restoration might require many adaptive management approaches. In some cases, restoration might be achieved passively by restoring natural streamflow dynamics. Regeneration of native plants requires the recovery of the natural flow conditions that allow for occasional flooding outside of the levees or the banks of the river, because native trees are dependent on flood events for the dispersal and germination of their seeds. Pulse flows, the release of water from dams that mimic natural flooding, may provide soil moisture, lower temperatures and increase oxygen of water, flush wastes and open space for germination and growth of native trees, and deliver important nutrients to the aquatic food web.

\section{Looking Back}

The ecological effects of tamarisk are highly variable across the landscape. Tamarisk can form dense, single-species stands or be part of a diverse plant community. Differences in ecological effects might also be because of tamarisk relative dominance, and (or) stand age. Environmental conditions also largely determine tamarisk's effects on the ecosystem. Despite all these sources of variation, there is evidence that tamarisk provides suitable habitat for some wildlife; uses the same amount of water as most native woody plants; and increases the intensity and frequency of wildfire in riparian systems.

Riparian forests in the Southwest are critically important habitat for wildlife. However, the amount and quality of riparian habitat has declined substantially, making the remaining habitat even more important to wildlife. Therefore, the loss of tamarisk could have a negative effect on some wildlife species, particularly those that use tamarisk extensively and with ranges confined to areas dominated by tamarisk.

\section{Looking Forward}

Tamarisk and the tamarisk leaf beetle will be important ecological players in the southwestern U.S. in the future. The tamarisk leaf beetle has the capacity to alter tamarisk's effects

\section{RIPARIAN VEGETATION WATER $_{\text {tootprint }_{y}}$}

waterfootprint.org/en/water-footprint/what-is-water-footprint
One droplet is 100 millimeters per year of water consumption All water consumption values are mean estimates based on values in the scientific literature. The range can vary based on environmental factors and leaf density and extent.

We wish to thank the late Arjen Hoestra for working with us in applying his water footprint concept to riparian vegetation.

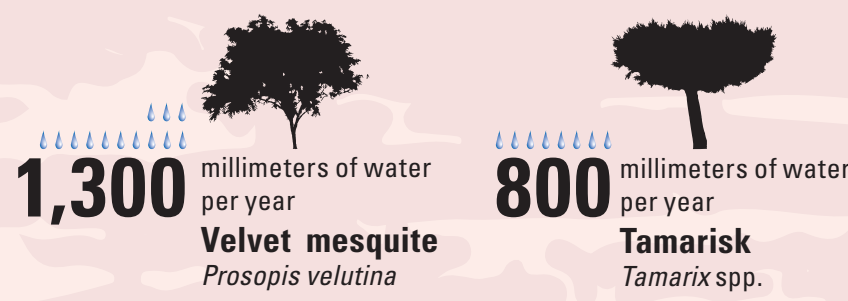

Prosopis velutina

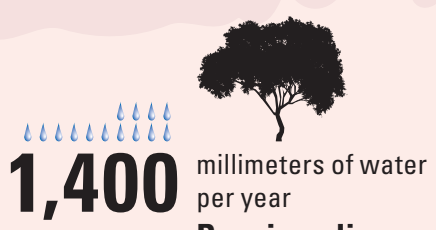

Russian olive

Elaeagnus angustifolia
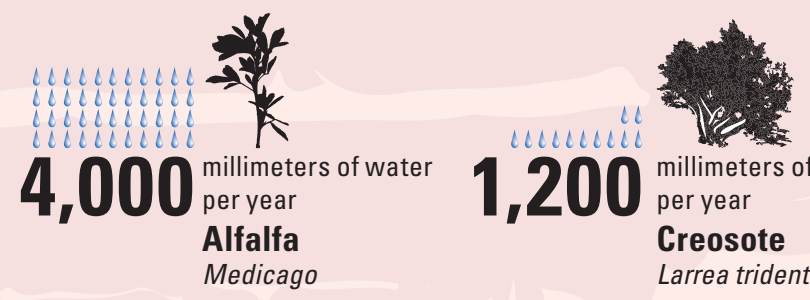

1,200 millimeters of water per year Creosote Larrea tridentata

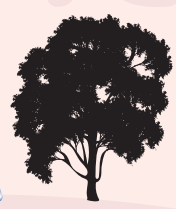

millimeters of water per year

Frémont's Cottonwood Populus fremontii
Goodding's black willow Salix gooddingii
1,000

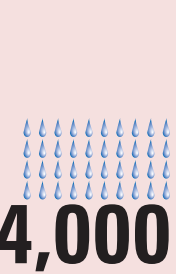

peryear

Sacaton grass Alcali sacaton

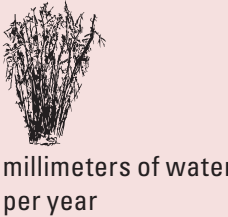

Giant reed

Arundo donax

By Pamela L. Nagler

Ilustration by Kimber Petersen

Diagram showing water consumption of native plant communities in the southwestern United States. Saltcedar (tamarisk) water consumption is similar to native woody riparian species. 
on riparian ecosystems, including effects on water savings, fire frequency, and wildlife habitat, although long-term impacts of the leaf beetle on riparian ecosystem function remain unclear.

USGS-led research has improved understanding of how tamarisk and the tamarisk leaf beetle are changing riparian ecosystems, what drives these changes, and what actions can promote rehabilitation of native plant communities and prevent future invasions. Federal partners, managers, and nongovernment organizations rely on USGS science to assist in making informed decisions about implementing adaptive management plans, particularly as the Southwest becomes warmer and drier.

Several areas of study remain high priorities such as:

- Understanding and monitoring changes in plant community and future state of riparian ecosystem functions

- Understanding long-term changes to riparian water use at different scales

- Monitoring and predicting where tamarisk leaf beetles are and the extent of tamarisk defoliation

- Understanding how beetle behavior will alter ecosystem services, such as water balance and fire regimes

- Understanding drivers in tamarisk eradicated areas and those that have been re-established has native habitat

- Identify best practices to actively restore tamariskinvaded systems before and after defoliation

- Understanding how tamarisk leaf beetles will change plant composition and river flow following tamarisk mortality

- Monitoring populations of southwestern willow flycatcher and other riparian wildlife dependent on tamarisk cover, biocontrol, and replacement species.

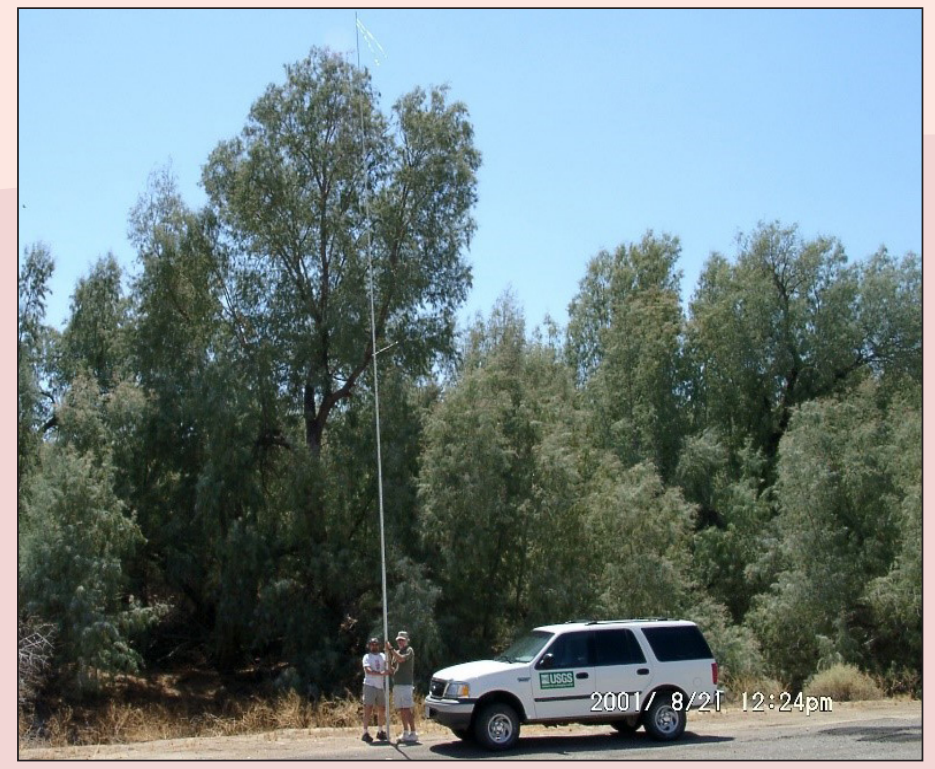

Photograph of tamarisk and native tree height, 2001. Photograph by Craig Westenberg, U.S. Geological Survey.

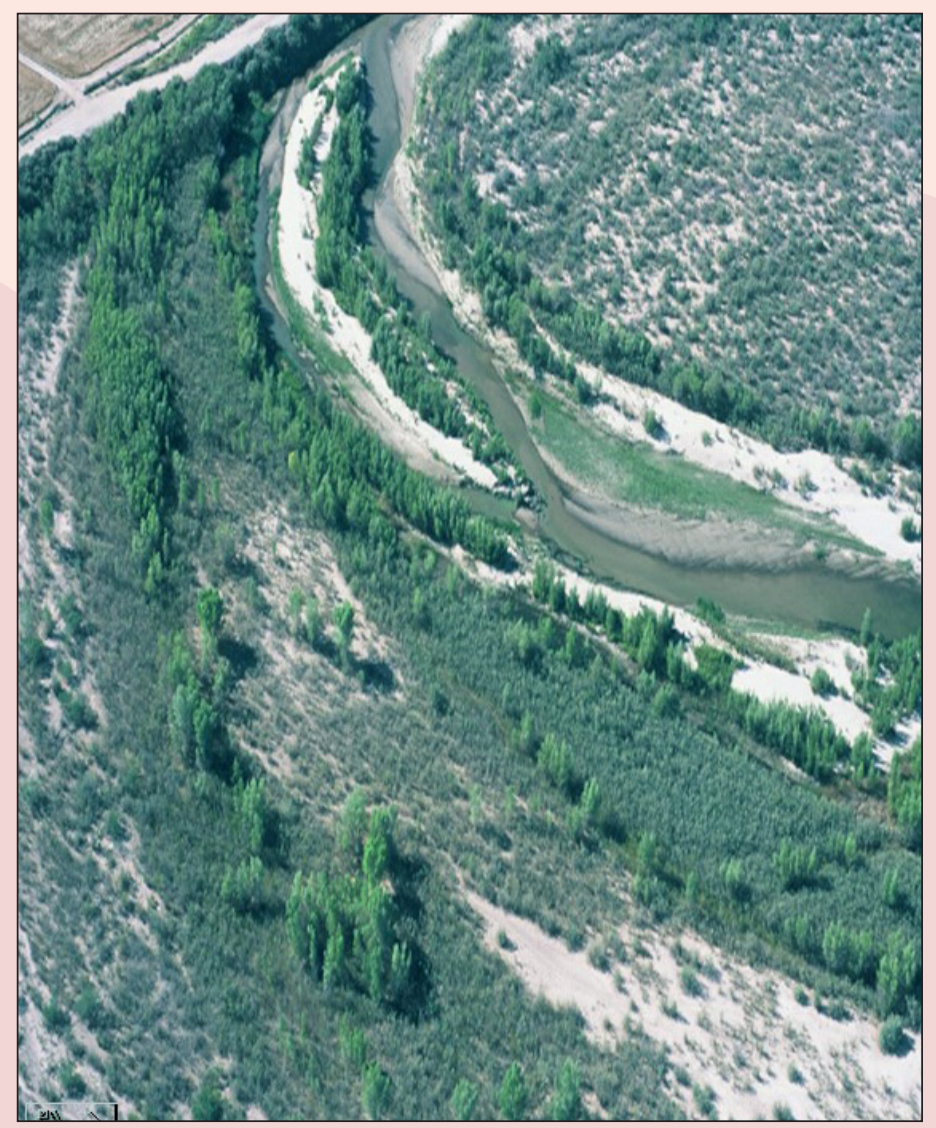

U.S. Geological Survey aerial photograph of tamarisk and native tree cohorts from overbank floods, 2002.

Tamarisk and tamarisk leaf beetles present new challenges and opportunities for land, water, and wildlife managers on western rivers. Monitoring of these riparian ecosystems will lead to new scientific findings related to biological control of nonnative species, quality of habitat for wildlife including sensitive species, native and nonnative plant water-use, and the extent and intensity of wildfires. These findings will help inform land and water management decisions.

\section{For more information contact:}

Pamela L. Nagler, Research Physical Scientist, USGS Southwest Biological Science Center pnagler@usgs.gov,

telephone: 520-670-3357, fax: 520-670-5592

By Pamela L. Nagler, Julia B. Hull, Charles van Riper II,

Patrick B. Shafroth, and Charles B. Yackulic

Edited by Aditya Navale and Phil Frederick

Layout and design by Kimber Petersen 